\title{
Strategi (BUMDes) Ciparasi Makmur Dalam Meningkatkan Pendapatan di Kabupaten Lebak Provinsi Banten
}

\author{
Atipah \\ Fisip Universitas Sultan Ageng Tirtayasa \\ htyp.97@gmail.com
}

\begin{abstract}
Abstrak
BUMDes adalah badan usaha yang dimaksudkan untuk memperkuat ekonomi desa. Dalam perkembangannya, BUMDes memiliki banyak masalah seperti yang dialami BUMDes Ciparasi Makmur. Masalah yang dihadapi seperti kurangnya sumber daya manusia, pendapatan yang terus menurun setiap tahun, kegiatan produksi masih mengandalkan pesanan, kurangnya inovasi produksi. Dalam penelitian ini teori yang digunakan adalah teori strategi, tahap strategi manajemen untuk melihat BUMDes Ciparasi Makmur dalam meminimalisir risiko dari masalah masing-masing masalah. Penelitian ini adalah deskriptif kualitatif. Hasil penelitian menunjukkan bahwa BUMDes Ciparasi Makmur memiliki beberapa langkah strategis seperti membimbing administrator dan anggota, mendorong penggunaan fasilitas dan infrastruktur, memberdayakan administrator untuk secara sukarela meminjamkan modal, mendorong pemerintah desa untuk meningkatkan alokasi, membangun wadah penyimpanan produksi.
\end{abstract}

Kata kunci : BUMDes, Ciparasi Makmur, Managemen Strategi

\begin{abstract}
BUMDes is a business entity intended to strengthen the village economy. In its development, BUMDes have many problems such as those experienced by BUMDes Ciparasi Makmur. Problems faced such as lack of human resources, income that continues to decline every year, production activities still rely on orders, the lack of production innovation. In this study the theory used is the strategy theory, the management strategy stage to see the BUMDes Ciparasi Makmur in minimizing the risk of the problems of each problem. This research is qualitative descriptive. The results showed that the BUMDes Ciparasi Makmur had several strategic steps such as guiding administrators and members, encouraging the use of facilities and infrastructure, empowering administrators to voluntarily lend capital, encouraging village governments to increase allocations, establishing production storage containers.
\end{abstract}

Keywords: BUMDes, Ciparasi Makmur, Strategy, Strategy Management 


\section{Pendahuluan}

Badan Usaha Milik Desa (BUMDes) merupakan lembaga usaha yang dimiliki Desa dalam upaya memperkuat perekonomian Desa dan dibentuk berdasarkan kebutuhan masyarakat dan potensi Desa. BUMDes merupakan bentuk kelembagaan Desa yang memiliki kegiatan menjalankan usaha ekonomi atau bisnis untuk memperoleh manfaat yang berguna bagi kesejahteraan masyarakat Desa (Faedlulloh, 2018). Desa mendirikan BUMDes bukanlah semata-mata untuk mencari keuntungan ekonomis atau laba, namun juga meliputi manfaat non ekonomi lainnya. Seperti yang diatur dalam Peraturan Menteri Desa Nomor 4 Tahun 2015 Tentang Pendirian, Pengurusan dan Pengelolaan, dan Pembubaran Badan Usaha Milik Desa. Dengan hadirnya BUMDes sebagai lembaga usaha Desa yang lahir atas pertimbangan kebutuhan dan potensi Desa, tentu sangat berpengaruh bagi Desa juga masyarakat di sekitarnya. Hasil dari pengelolaan BUMDes yang disebut keuntungan akan menjadi pemasukan Desa atau disebut Pendapatan Asli Desa (PAD). Dalam buku pedoman BUMDes (2007) mengatur mengenai peran serta pengurus Badan Usaha Milik Desa untuk bersama-sama mewujudkan tujuan dibentuknya BUMDes. Badan Usaha Milik Desa sebagai lembaga usaha di Desa tentu melibatkan masyarakat sebagai pendukung keberhasilan tujuan BUMDes. Selain masyarakat langsung, BUMDes melibatkan tiga peran penting dalam upaya mewujudkan masyarakat yang sejahtera melalui peningkatan pendapatan Desa. Peran tersebut terbagi atas badan pengurus, badan Pengelola dan badan Pengawas.

Adapun badan pengurus terdiri atas satu orang ketua dan dua orang anggota (sekertaris dan bendahara). Badan pengelola BUMDes adalah mereka yang memiliki kompetensi untuk dapat mengelola bidang yang akan dilaksanakan oleh BUMDes, latar belakang pendidikan minimal SMU sederajat. Dalam pengelolaan BUMDes harus mengacu pada tata aturan yang sudah disepakati bersama sebagaimana yang telah tertuang dalam AD/ART BUMDes. Pengelolaan harus transparan/terbuka sehingga ada mekanisme check and balance baik oleh Pemerintahan Desa maupun masyarakat, serta perlu adanya susunan-susunan rencana pengembangan BUMDes. Beberapa peluang pengembangan ekonomi Desa melalui Badan Usaha Milik Desa (BUMDes) dengan fokus menggerakkan potensi lokal antara lain: Pertama, bisnis lokal sederhana yang memberikan pelayanan umum kepada masyarakat dengan memperoleh keuntungan finansial. Kedua, bisnis penyewaan barang-barang untuk melayani kebutuhan masyarakat Desa dengan tujuan memperoleh Pendapatan Asli Desa (PAD). Ketiga, usaha perantara (brokering) yang memberikan jasa pelayanan kepada warga. Keempat, bisnis yang berproduksi dan atau berdagang barang-barang tertentu untuk memenuhi kebutuhan masyarakat maupun dipasarkan pada skala pasar yang lebih 
luas. Kelima, bisnis keuangan yang memenuhi kebutuhan-kebutuhan usaha mikro yang dijalankan oleh pelaku usaha ekonomi Desa yang dapat memberikan akses kredit dan peminjaman yang mudah diakses oleh masyarakat Desa. Keenam, usaha bersama (holding) sebagai induk dari unit-unit usaha yang dikembangkan masyarakat Desa baik dalam skala lokal Desa maupun kawasan pedesaan ). Kecamatan Sobang Kabupaten Lebak tercatat memiliki 10 unit Badan Usaha Milik Desa yang tersebar di 10 Desa dengan berbeda-beda jenis usaha sesuai dengan kebutuhan desa tersebut. Pemerintah desa Ciparasi Kecamatan Sobang meresmikan pendirian BUMDes Ciparasi Makmur pada 15 Desember 2015. Pembentukan tersebut mengacu pada Peraturan Desa Ciparasi Kecamatan Sobang Kabupaten Lebak Nomor: 08 Tahun 2015 tentang Pembentukan Badan Usaha Milik Desa (BUMDes). Melalui kesepakatan bersama antara Badan Permusyawaratan Desa dan Kepala Desa Ciparasi memutuskan dan menetapkan Peraturan Desa tentang Badan Usaha Milik Desa Ciparasi. Lembaga tersebut merupakan upaya dalam meningkatkan pendapatan desa sesuai dengan kebutuhan dan potensi desa.

Bidang usaha yang dikelola oleh BUMDes Ciparasi Makmur adalah usaha Rumah Produksi Bata Beton (paving block). Bata beton adalah suatu komposisi bahan bangunan yang terbuat dari campuran semen portland atau bahan perekat hidrolis lainnya, air dan agregat dengan atau tanpa bahan tambahan lainnya yang tidak mengurangi mutu beton tersebut. Bata beton memiliki nilai estetika yang bagus, karena selain memiliki bentuk segiempat, tahu, trihex ataupun segibanyak dapat pula berwarna seperti aslinya ataupun diberikan zat pewarna dalam komposisi pembuatan. Bata beton ini sendiri berfungsi untuk lantai yang banyak digunakan di luar bangunan serta tidak boleh retak-retak dan cacat. Bata beton adalah solusi terbaik untuk lahan resapan saat hujan dan banjir. Pemasangannya tidak susah dan perawatannya pun mudah. Pemasangan dengan motif yang baik akan menambah keindahan bangunan sekitarnya. Bata beton diproduksi dengan warna natural, reguler (merah, hitam) dan warna khusus (hijau, kuning, biru).

Melalui wawancara langsung dengan Kepala Desa Ciparasi mengungkapkan bahwa BUMDes Ciparasi Makmur memilik beberapa strategi, yaitu (1) Aspek Pemasaran dengan memperkenalkan produk/kegiatan usaha kepada masyarakat, melakukan kerjasama dengan lembaga/dinas instansi, menyebarluaskan famplet dan sebagainya. (2) Aspek Produksi dengan mengutamakan produk yang bermutu, menetapkan jumlah produksi harian dan sebagainya. (3) Aspek Organisasi dan SDM dengan membentuk unit usaha baru, melakukan rekrutmen sesuai kebutuhan, melakukan pengembangan SDM yang ada dan sebagainya. (4) Aspek Keuangan 
dengan melakukan pembukuan penetapan modal unit usaha, membukukan rencana anggaran pendapatan dan biaya (RAPB) unit usaha dan sebagainya.

Peluang dan kesempatan pasar yang dapat mendukung keberhasilan BUMDes belum sepenuhnya berjalan dengan baik, banyaknya kendala menjadi hambatan dalam mengembangkan usaha bata beton, akan tetapi meskipun demuikian, BUMDes tetap beroiperasi dan menerima pesanan dari manapun. Peneliti menemukan beberapa masalah dalam pelaksanaan pengelolaan produksi bata beton. Adapun beberapa permasalahannya adalah: Pertama, minimnya SDM rumah produksi bata beton sehingga belum mampu memproduksi secara masal. Sejak didirikannya BUMDes Ciparasi Makmur hanya mampu menerima 4 orang karyawan yang diambil dari masyarakat desa setempat. Kedua, pendapatan menurun setiap tahunnya. Berdasarkan data yang diperoleh sejak tahun 2015 sampai dengan tahun 2018 belum adanya kenaikan yang signifikan, produksi bata beton terus mengalami penurunan. Pada tahun 2016 diperoleh sebesar Rp. 184.600.000, Kemudian tahun 2017 mengalami penurunan sekitar 19,01\% atau sebesar Rp. 149.500.000. Selanjutnya pada tahun 2018 kembali menurun yaitu sekitar 15,05\% atau pendapatan sebesar Rp. 127.000.000. Kondisi tersebut semakin menurun tiap tahunnya menandakan adanya kendala yang terjadi pada pengelolaan BUMDes Ciparasi Makmur.

Ketiga, kegiatan produksi masih mengandalkan pemesanan. Dalam hal ini karyawan akan bekerja apabila ada pesanan, dan jika tidak ada maka seluruh karyawan dirumahkan. Keempat, melakukan pinjam modal untuk biaya produksi pavlingblock apabila ada pesanan. Hal ini dikarenakan tidak adanya simpanan dana yang bisa digunakan sebagai modal cadangan untuk produksi, sehingga menawarkan uang muka seadanya sebagai tanda jadi dan pengurus BUMDes akan pinjam modal kepada siapapun yang memiliki uang untuk modal produksi sesuai pesanan, adapun pembayaran dilakukan setelah bata beton dibayar lunas oleh konsumen. Kelima, produk bata beton hanya memiliki 2 model yaitu jenis kotak (sisi 4) dan jenis bulat (sisi 5), disadari oleh pengurus bahwa masih kurang kreasi dan inovasi karena hanya memiliki 2 alat cetak tersebut.

\section{Kerangka Teori}

Konsep Analisis SWOT

\begin{tabular}{|c|c|c|}
\hline FAKTOR INTERNAL & STRENGTHS (S) & WEAKNESSES (W) \\
FAKTOR & Daftarkan 5-10 kekuatan & Daftarkan 5-10 \\
EKSTERNAL & Internal disini & kekuatan Internal \\
\hline
\end{tabular}




\begin{tabular}{|c|c|c|}
\hline OPPORTUNITIES (O) & disini \\
$\begin{array}{c}\text { Daftarkan 5-10 } \\
\text { kekuatan eksternal } \\
\text { disini }\end{array}$ & $\begin{array}{c}\text { Buat strategi disini yang } \\
\text { menggunakan kekuatan } \\
\text { untuk memanfaatkan } \\
\text { peluang }\end{array}$ & $\begin{array}{c}\text { STRATEGI W-O } \\
\text { Buat strategi disini } \\
\text { peluang untuk } \\
\text { mengatasi kelemahan }\end{array}$ \\
\hline $\begin{array}{c}\text { THREATS (T) } \\
\text { Daftarkan 5-10 } \\
\text { kekuatan Eksternal } \\
\text { disini }\end{array}$ & $\begin{array}{c}\text { STRATEGI S-T } \\
\text { menggunakan kekuatan } \\
\text { untuk menghindari } \\
\text { ancaman }\end{array}$ & $\begin{array}{c}\text { STRATEGI W-T } \\
\text { Buat strategi disini } \\
\text { kelemahan dan } \\
\text { menghindari } \\
\text { ancaman }\end{array}$ \\
\hline
\end{tabular}

Sumber: David dan Whellen (2003:231)

\section{Metode Penelitian}

Dalam penelitian ini peneliti menggunakan metode penelitian kualitatif yang bersifat deskriptif dan cenderung menggunakan analisis. Dalam melakukan penelitian kualitatif akan dilengkapi dengan sumber data sebagai pendukung guna menyempurnakan penelitian menggunakan metode ini. Adapun sumber data yang dimaksud adalah sumber data primer dan sumber data sekunder.

Adapun fokus dalam penelitian ini untuk mengetahui atau merujuk pada strategi BUMDes Ciparasi Makmur dalam meningkatkan pendapatan desa melalui rumah Produksi Pavlingblok. Dengan demikian Untuk memperoleh data yang diperlukan penulis melakukan pengumpulan data dengan cara observasi, wawancara, dokumentasi, dan studi pustaka.

Penelitian ini adalah penelitian deskriptif, dengan lebih banyak bersifat uraian dari hasil wawancara dan studi dokumentasi. Data yang telah diperoleh akan dianalisis secara kualitatif serta diuraikan dalam bentuk deskriptif. Teknik analisis data yang digunakan dalam penelitian ini adalah menggunakan langkah-langkah seperti yang dikemukakan oleh Burhan Bungin (2003:70) yaitu: Pengumpulan Data (Data Collection), Reduksi Data (Data Reduction), Penyajian Data (Data Display), Verifikasi dan Penegasan Kesimpulan.

peneliti menggunakan teknik triangulasi sumber (data) dan teknik triangulasi metode untuk menguji keabsahan data yang berhubungan dengan masalah penelitian 
yang diteliti. Pada triangulasi sumber (data) peneliti melakukan wawancara mendalam dengan ketua Bumdes Ciparasi Makmur, Pengurus Bumdes, perangkat Desa seperti Kepala Desa dan sekretaris Desa Ciparasi, Masyarakat Desa Ciparasi sebagai pengguna produk pavlingblock, mantan kepala Desa Ciparasi dan pihak kecamatan bidang pemberdayaan masyarakat desa. Hal tersebut dilakukan tidak lain untuk mengumpulkan data dari beberapa informan terkait pelaksana program Bumdes dan tidak berpihak pada satu sumber informan.

Maka setiap tahap dalam proses tersebut dilakukan untuk mendapatkan kearifan data dengan mengkaji seluruh data yang ada dari berbagai sumber yang telah didapat peneliti dari lapangan dalam bentuk dokumen pribadi, dokumen resmi, gambar, foto dan sebagainya melalui metode wawancara yang didukung dengan studi dokumentasi.

Pada penelitian ini, penentuan informan dibagi menjadi dua yaitu key informan dan secondary informan. Key informan sebagai informan utama yang lebih mengetahui situasi fokus penelitian sehingga perannya tidak dapat digantikan oleh orang lain, sedangkan secondary informan sebagai informan penunjang dalam memberikan penambahan informasi. Dalam penelitian kualitatif penentuan informan dapat dilakukan dengan menggunakan teknik Purposive atau snowball. Dalam penelitian ini, peneliti menentukan informan dengan cara menggunakan teknik Purposive.

Menurut Sugiyono (2012:218-219) purposive adalah teknik pengambilan sumber data dengan pertimbangan tertentu. Pertimbangan tersebut dipandang dari 2 hal yakni yang pertama yaitu orang-orang yang memiliki keterkaitan terhadap BUMDes Ciparasi Makmur dan kedua yaitu masyarakat/penduduk sekitar untuk dijadikan pandangan dalam memberikan masukan dan penilaian.

Adapun yang menjadi instrumen dalam penelitian ini berasal dari perangkat desa dan pengurus Badan Usaha Milik Desa Ciparasi Makmur serta masyarakat sekitar wilayah Desa Ciparasi. Pemilihan instrumen penelitian ini disesuaikan dengan kebutuhan penelitian yang dianggap relevan.

Lokasi penelitian merupakan tempat peneliti melakukan agenda penelitian. Terdapat beberapa faktor yang harus dipertimbangkan oleh peneliti, sehingga penentuan lokasi penelitian ini dimaksudkan untuk memperkecil ruang lingkup dalam pembahasan dan sekaligus untuk mempertajam fenomena sosial yang ingin dikaji dalam hal ini yaitu Upaya Badan Usaha Milik Desa (BUMDes) Ciparasi Makmur dalam Meningkatkan Pendapatan Desa melalui Rumah Produksi Pavlingblok. Dalam melaksanakan penelitian ini, peneliti mengambil lokasi penelitian di Desa Ciparasi Kecamatan Sobang Kabupaten Lebak Banten. 


\section{Hasil dan Diskusi}

Desa Ciparasi merupakan desa yang secara administrasi berada di wilayah Kecamatan Sobang, Kabupaten Lebak, Provinsi Banten. Desa ini memiliki luas wilayah sebesar 468 hektar dengan ketinggian sekitar 800 meter dari atas permukaan laut. Kondisi geografis yang terdiri dari daerah lembah dan sungai menjadikan sektor agraris sebagai sektor utama dalam matapencaharian masyarakat desa setempat. Oleh karenanya, dari seluruh luas wilayah desa, 325,48 hektar merupakan lahan garapan pertanian dan 124,94 hektar adalah lahan perkebunan.

Beragamnya mata pencaharian masyarakat desa tentu tidak dapat memberikan dampak perekonomian yang signifikan terhadap keberlangsungan pemerintahan desa. Untuk itu diperlukan adanya suatu badan khusus sebagai upaya desa dalam meningkatkan pendapatan ekonomi. Maka dibentuklah Badan Usaha Milik Desa (BUMDes) yang menjadi satu dari sekian solusi untuk dapat meningkatkan pendapatan desa.

Badan Usaha Milik Desa (BUMDes) Ciparasi yang bernama BUMDes Ciparasi Makmur dibentuk pada tanggal 15 Desember 2015 melalui Peraturan Desa Nomor 08 Tahun 2015. Pembentukan badan usaha tersebut merupakan hasil prakarsa masyarakat melalui kesepakatan bersama antara Badan Permusyawaratan Desa dan Kepala Desa Ciparasi. Adapun usaha yang dilakukan adalah membuat dan memproduksi bata beton (bata beton). Tujuan dibentuknya BUMDes adalah sebagai optimalisasi pemberdayaan masyarakat sesuai dengan potensi yang dimiliki Desa Ciparasi secara terorganisir, terstuktur, dan tepat sasaran.

Seperti halnya organisasi lain, BUMDes Ciparasi Makmur pun memerlukan anggota untuk dapat melaksanakan tugasnya secara efektif. Dalam perekrutan pegawai, terdapat mekanisme tertentu yang dilakukan oleh para pengurus BUMDes Ciparasi Makmur. Begitu pula dengan apa yang diungkapkan oleh Fathurrohman (wawancara, 21 Mei 2019) bahwa terdapat mekanisme tersendiri dalam perekrutan pegawai BUMDes Ciparasi Makmur.

Sebagai sebuah badan usaha, tentu BUMDes Ciparasi Makmur memiliki fokus tertentu dalam menjalankan usaha tersebut. BUMDes Ciparasi Makmur bergerak di bidang produksi bata beton yang menjadi satu-satunya jenis usaha yang dijalankan. Hal ini pun dikemukakan oleh Ketua BUMDes Ciparasi Makmur dalam wawancara pada tanggal 21 Mei 2019. "Jadi di BUMDes Ciparasi Makmur ini kami hanya fokus pada satu jenis usaha, yakni rumah produksi bata beton (bata beton). Hal ini dikarenakan bata beton merupakan salah satu kebutuhan masyarakat desa."

Menjadikan bisnis bata beton sebagai fokus utama tentu bukan tanpa alasan. Fathurrohman, Kepala Desa Ciparasi mengungkapkan bahwa jenis usaha bata beton 
dipilih karena melihat potensi desa di mana kebutuhan akan bata beton biasanya hanya dapat diperoleh di luar desa.

Pengelolaan BUMDes Ciparasi Makmur oleh Kepala Desa Ciparasi dianggap sudah cukup baik dari segi perencanaan hingga pelaksanaan usaha sesuai dengan Anggaran Dasar dan Anggaran Rumah Tangga (AD/ART) badan usaha tersebut. Dalam AD/ART BUMDes Ciparasi Makmur dibahas mengenai penanaman modal hingga tata cara pelaksanaan penyelenggaraan BUMDes. Rancangan tersebut apabila sudah mencapai kesepakatan akan diaplikasikan ke dalam RKPDes (Rencana Kegiatan Pembelanjaan Desa). BUMDes Ciparasi Makmur dalam melaksanakan tugasnya diawasi oleh BPD dan bertanggungjawab kepada Pemerintah Desa.

Sebagai sebuah badan usaha, BUMDes tentu akan sangat memperhitungkan untung dan rugi serta proyeksi pasar. Bagi Pemerintah Desa Ciparasi, pembentukan BUMDesa Ciparasi merupakan sebuah kebutuhan serta solusi dari beberapa persoalan yang sulit tersentuh oleh pemerintah daerah bahkan pemerintah desa sekalipun. Kondisi geografi memperlihatkan Desa Ciparasi berada di daerah yang jauh dari pusat kota Kabupaten Lebak yang menjadikan masyarakat acapkali kesulitan dalam mendapatkan bahan atau material bangunan.

Pemanfaatan peluang usaha oleh BUMDes Ciparasi makmur juga diharapkan membawakan manfaat selain untuk mempermudah masyarakat setempat juga diharapakan dapat meningkatkan pendapatan desa perekonomian desa. Selanjutnya, fokus BUMDes Ciparasi Makmur pada bidang produksi bata beton bukan hanya dilatarbelakangi sebagai upaya peningkatan pendapatan desa saja, tetapi juga didasarkan atas apa yang selama ini menjadi keluhan masyarakat, hal tersebutlah yang menjadi peluang untuk berdirinya BUMDes Ciparasi Makmur.

BUMDes Ciparasi Makmur yang berdiri belum genap 4 tahun tentu tidak lepas dari berbagai kelemahan yang dimiliki. Kelemahan tersebut antara lain:

1. Keterbatasan Alat Produksi

2. Keterbatasan Modal

3. Sumber Daya Manusia Pengurus dan Anggota BUMDes

4. Dalam upaya peningkatan pendapatan desa, tidak sedikit ancaman yang dihadapi oleh

BUMDes Ciparasi Makmur. Ancaman tersebut ialah kesadaran masyarakat dalam pengembangan BUMDes salah-satunya ialah masih adanya beberapa pembeli yang menunggak pembayaran bata beton sehingga menyebabkan tersendatnya perputaran uang BUMDes Ciparasi Makmur. 


\section{Kesimpulan}

BUMDes Ciparasi Makmur dalam kondisi organisasi yang kuat dan berpeluang akan melakukan langkah-langkah organisasi seperti dalam upaya meningkatkan pendapatan desa. Strategi yang diambil dalam kondisi ini adalah melakukan pemberdayaan dan mendorong para pengurus untuk mau memberikan pinjaman modal secara sukarela untuk menalangi kebutuhan modal saat keuangan BUMDes tersendat serta membuat penampungan hasil produksi pavingblock.

Selanjutnya, dalam kondisi BUMDes Ciparasi Makmur menghadapi peluang pasar yang sangat besar, tetapi di lain pihak menghadapi beberapa kendala atau kelemahan internal. strategi yang diambil ialah melakukan pengoptimalan kinerja para Pengurus BUMDes, kemudian mengubah pola pikir pengurus BUMDes melalui pembinaan agar mau bergerak. Kemudian, dalam suatu posisi dimana BUMDes Ciparasi Makmur menghadapi tantangan yang besar dan memiliki kekuatan untuk memanfaatkan peluang jangka panjang, strategi yang diambil adalah mendorong pemerintah desa untuk menambah modal pembiayaan BUMDes melalui penerbian PerDes (Peraturan Desa) agar BUMDes memiliki modal yang kuat.

Terakhir, dalam suatu kondisi BUMDes dalam posisi yang lemah dan menghadapi tantangan besar BUMDes Ciparasi Makmur mencoba untuk menggunakan strategi bertahan, dalam melakukan pengendalian kinerja internal agar tidak mengarah pada kebangkrutan. Dalam kondisi tersebut, strategi yang diambil adalah penambahan sarana dan prasarana BUMDes, menambah anggota atau pegawai, melakukan melakukan penyuluhan.

Saran yang dapat diberikan oleh peneliti yaitu: 1) BUMDes haruslah berdiri atas dasar kebutuhan masyarakat bukan hanya sebatas menggugurkan kewajiban pemerintah desa saja. 2) BUMDes Ciparasi Makmur perlu melakukan pengkajian kembali terhadap isu strategis dalam upaya peningkatan pedapatan desa agar penurunan pendapatan yang di alami setiap tahun dapat berangsur naik dan benarbenar mampu memberikan sumbangsih yang jelas baik kepada masyarakat maupun pada Pemerintah Desa Ciparasi.

\section{Referensi}

Adawiyah, Robiatul (2018), Strategi Pengembangan Badan Usaha Milik Desa (BUMDes) Berbasis Aspek Modal Sosial / jurnal Kebijakan dan Manajemen Publik / Volume 6, Nomor 3, September - Desember 2018 / Universitas Airlangga

Adisasmita, Rahardjo. (2010). Pembiayaan Pembangunan Daerah. Yogyakarta: Graha Ilmu. AD/ART BUMDes Ciparasi Makmur, Kecamatan Sobang / Lebak - Banten tahun 2015 
David, Fred R. (2010) Strategic Management; Penerbit Salemba Empat

David, Hunger, J. \& Wheelen, Thomas L. (2003). Manajemen Strategis. Yogyakarta: Penerbit Andi

Faedlulloh, D. (2018). BUMDes dan Kepemilikan Warga: Membangun Skema Organisasi Partisipatoris. Journal of Governance, 3(1), 1-17. https://doi.org/10.31506/jog.v3i1.3035

Fitriska, Kateria (2-17) Strategi Pengembangan Badan Usaha Milik Desa Dalam Meningkatkan Kesejahteraan Masyarakat di Desa Lancang Kuning Kecamatan Bintan Utara / Jurnal Ilmu Administrasi Negara (JUAN) / Vol. 5 No. 2 November Tahun 2017 / Ilmu Administrasi Negara FISP UMRAH)

Halomoan, Rio (2017) Strategi Pemerintah Daerah Dalam Pengembangan Badan Usaha Milik Desa Di Kabupaten Rokan Hulu Tahun 2012-2014 / JOM FISIP Vol. 4 No. 1 - Februari 2017 / Universitas Riau

Hidayat, Akhmad Bagus (2016) Strategi Pengelolaan Badan Usaha Milik Desa (BUMDesa) Dalam Upaya Pengembangan BUMDesa Surya Sejahtera Desa Kedungturi Kecamatan Taman Kabupaten

Husein, Umar. (2010). Riset Pemasaran dan Bisnis. Jakarta: Gramedia Pustaka Utama

Kusuma (1987) 1987. Psiko Diagnostik. Yogyakarta: SGPLB Negeri Yogyakarta.

Laporan Realisasi Anggaran Pendapatan dan Belanja Desa Tahun 2016

Maleong, Lexy J. (2007). Metodologi Penelitian Kualitatif. Bandung: PT. Remaja Rosdakarya Offset

Panduan Pendirian dan Pengelolaan Badan Usaha Milik Desa (Bumdes) Departemen Pendidikan Nasional Pusat Kajian Dinamika Sistem Pembangunan (PKDSP), 2007. Fakultas Ekonomi Universitas Brawijaya.

Peraturan Pemerintah No 72 tahun 2005 tentang Desa.

Peraturan Menteri Dalam Negeri No. 39 Tahun 2004

Permendagri No 37 Tahun 2007 tentang Pedoman Pengelolaan Keuangan Desa

Peraturan Menteri Dalam Negeri Nomor 39 Tahun 2010 Tentang Badan Usaha Milik Desa

Peraturan Menteri Desa Nomor 4 Tahun 2015 Tentang Pendirian, Pengurusan dan Pengelolaan, dan Pembubaran Badan Usaha Milik Desa 
Volume 1 Issue 1, April 2019

http://hk-publishing.id/ijd-demos

Peraturan Desa Ciparasi Nomor 08 Tahun 2015 Tentang Pembentukan Badan Usaha Milik Desa (BUMDes)

Sedarmayanti (2014) Manajemen Strategi. Bandung: PT. Refika Aditama. 